Givan Dwiguna, Adil Mubarak I Implementasi Pengembangan Energi Baru Terbarukan Pembangkit Listrik Tenaga Mikro Hidro (PLTMH) oleh Dinas Energi dan Sumber Daya Mineral Provinsi Sumatera Barat di Solok Selatan

\title{
IMPLEMENTASI PENGEMBANGAN ENERGI BARU TERBARUKAN PEMBANGKIT LISTRIK TENAGA MIKRO HIDRO (PLTMH) OLEH DINAS ENERGI DAN SUMBER DAYA MINERAL PROVINSI SUMATERA BARAT DI SOLOK SELATAN
}

\author{
Givan Dwiguna $^{1(a)}$, Adil Mubarak ${ }^{2(b)}$ \\ ${ }^{1}$ Jurusan Ilmu Administrasi Negara, Universitas Negeri Padang \\ ${ }^{2}$ Jurusan Ilmu Administrasi Negara, Universitas Negeri Padang \\ a)givandwiguna20@gmail.com, ${ }^{b}$ adilmubarak@fis.unp.ac.id
}

\begin{abstract}
This study aims to determine the Renewable Energy Development Implementation in South Solok Regency. New and Renewable Energy is clean energy that is rich in diversity and quantity such as solar energy, wind, natural gas, ocean waves, garbage, wood, biomass, nuclear and water (microhydro). New and Renewable Energy was developed by the West Sumatra Provincial ESDM Office in the South Solok area since 2013, however, in implementing this development there were still some obstacles which was faced by the West Sumatra Provincial ESDM Office as the community which has not felt the impact of developing the benefits of PLTMH. It was because there were some PLTMH which were not functioning or have damaged caused by natural disasters such as floods and landslides, there was still a lack of technicians to repair the damage to the PLTMH, there was still a lack of costs obtained from PLTMH customers who aimed to repair damage to PLTMH generators and turbines. This study was a qualitative research which used descriptive method. The research respondents were selected by using a purposive sampling technique. For the data collection, this study used interview guidelines, observation, and documentation of the research as the instrumentation. The validation technique used the triangulation method. Furthermore, the data analysis technique was reducing data, displaying data, and drawing the conclusions of the study which has been conducted. The findings showed that the Renewable Energy Development implementation for Micro Hydro Power Plants (PLTMH) by the ESDM Office of West Sumatra Province in South Solok was still not running as it should be, because there were still some obstacles which were faced in developing of New Renewable Energy of PLTMH that the results was not being implemented properly. Supporting factors for the implementation of this PLTMH development were the data and information, communication, bureaucratic attitudes, and organizational structure. While communication, organizational characteristics, economic environment and human resources were the inhibiting factors. The Effort to overcome these obstacles was the government has signed several commitments related to the development of Renewable Energy. Beside that, to fill the conditions of the national electricity, the government has also involved the private sector.
\end{abstract}

Keywords : Implementation, Renewable Energy Development, Micro Hydro, Power Plants

Corresponding author. Email. givandwiguna20@gmail.com

How to cite this article. Dwiguna, Givan \& Mubarak, Adil. (2020). Implementasi Pengembangan Energi Baru Terbarukan Pembangkit Listrik Tenaga Mikro Hidro (PLTMH) oleh Dinas Energi dan Sumber Daya Mineral Provinsi Sumatera Barat di Solok Selatan. Jurnal Mahasiwa Ilmu Administrasi Publik (JMIAP) Jurusan Ilmu Administrasi Negara Fakultas Ilmu Sosial Universitas Negeri Padang, Volume 2 (4), Hal. 28-35.

http://jmiap.ppj.unp.ac.id

ISSN : 2684-818X (Online), ISSN : 2338-7378 (Print)

Copyright $\bigcirc 2020$. Published by Labor Jurusan Ilmu Administrasi Negara FIS UNP, Padang 
Givan Dwiguna, Adil Mubarak I Implementasi Pengembangan Energi Baru Terbarukan Pembangkit Listrik Tenaga Mikro Hidro (PLTMH) oleh Dinas Energi dan Sumber Daya Mineral Provinsi Sumatera Barat di Solok Selatan

\section{PENDAHULUAN}

Energi baru dalam Perpres No. 5 Tahun 2006 tentang Kebijakan Energi Nasional, merupakan salah satu bentuk energi yang dihasilkan teknologi baru baik yang berasal dari energi terbarukan maupun energi yang tidak terbarukan. Energi baru yang dimaksud ialah coal bed methane, batubara yang dicairkan (liquefied coal), hidrogen, nuklir dan batubara yang digaskan (gasified coal). Energi terbarukan dihasilkan oleh sumber (resource) daya energi yang bersifat alamiah, yang mana tidak akan habis sehingga dapat bekelanjutan jika melalui pengelolaan yang baik. Contoh energi terbarukan tersebut diantaranya panas bumi, panas surya, angin, aliran air sungai, bahan bakar nabati (biofuel), biogas, biomassa, suhu kedalaman laut, dan ombak laut.

Energi baru terbarukan merupakan energi bersih yang beragam sumbernya dan tidak terbatas jumlahnya. Sumber energi terbarukan dapat berasal dari angin, matahari, air (mikrohidro), gelombang laut, panas bumi, sampah, biomassa dan nuklir. Terdapat beberapa kelebihan dari penggunaan energi baru terbarukan khususnya di Indonesia, diantaranya: 1) Tersedia dalam beragam sumber dan jumlah yang banyak, 2) Potensi besar energi baru terbarukan di Indonesia yang jauh lebih bersih sekaligus terjangkau, 3) Ramah lingkungan dalam artian energi baru terbarukan dapat mengurangi kadar emisi di udara akibat penggunaan energi fosil, dan 4) Mudah diperoleh, dengan iklim tropis maritim, dan berada di jalur api Indonesia berpotensi menghasilkan energi baru terbarukan yang berasal dari matahari, panas bumi, angin dan air.

Pembangkit Listrik Tenaga Mikrohidro disingkat PLTMH, sesuai namanya mikro, mempunyai arti kecil dan hidro yang bermakna air, merupakan versi skala kecil pembangkit listrik dengan pemanfaatan tenaga air sebagai daya penggerak utamanya. Selayaknya sungai, saluran irigasi, dan air terjun alam dengan pemanfaatan banyaknya debit air dan tinggi terjunan (head).

Dalam hal teknis, terdapat 3 elemen utama dalam sistem mikrohidro, yakni air, turbin dan generator. Energi yang ditimbulkan mikrohidro diperoleh dari arus atau aliran air yang mempunyai ketinggian tertentu. Energi listrik dari mikrohidro diperoleh melalui pemanfaatan energi potensial dari head (jatuhan air). Energi listrik yang dihasilkan dari energi potensial air berbanding lurus dengan ketinggian jatuhan air.. Adapun manfaat keuntungan dari PLTMH adalah: 1) Murah, sebab memanfaatkan energi yang tersedia dialam, 2) Konstruksi yang digunakan cenderung sederhana, 3) Minim pencemaran/polusi, 4) Dapat diintegrasikan dengan model program yang sejenis, contohnya seperti irigasi dan perikanan, dan 5) menumbuhkan kesadaran masyarakat akan kelestarian lingkungan terutama hutan sehingga memunculkan jaminan atas ketersediaan air.

Provinsi Sumatera Barat masih mengalami kekurangan listrik dikarenakan keterbatasan PLN dalam memperluas jangkauan jaringan listrik untuk mengaliri desa atau rumah tangga yang terisolir. Edrizal selaku Kepala Bidang Energi dan Ketenagalistrikan, Dinas Energi Sumber Daya Mineral (ESDM) Sumatera Barat, berdasarkan data tahun 2017 menyebut ada sebanyak 167.633 RT belum teraliri listrik, sementara yang telah dialiri listrik ada sebanyak 1.066.776 RT. Data ini menunjukkan bahwa masih banyak keluarga di Sumatera Barat yang rumahnya belum menikmati aliran listrik.

Salah satu daerah yang ada di Sumaetra Barat yaitu Kabupaten Solok Selatan masih mengalami kekurangan energi listrik. Menurut DESDM Sumatera Barat di Kabupaten Solok Selatan terdapat 1795 KK atau rumah tangga yang tidak terlistriki oleh jaringan PLN yang terdapat di 7 kecamatan dan 20 jorong ataudesa. Menurut Bapak Edrizal Kepala Bidang energi dan kelistrikan Hal itu dikarenakan tidak 
terjangkau nya desa atau rumah oleh jaringan listrik PLN dengan alasan jarak desa dengan jaringan listrik PLN sangat jauh dan medan menuju desa tersebut sangat rumit serta rumah di desa tersebut sangat sedikit, ada juga lantaran ketidakmampuan KK untuk melakukan penyambungan listrik ke PLN padahal rumah tersebut dapat dijangkau oleh jaringan PLN.

Dinas ESDM Provinsi Sumatera Barat memiliki kewenangan dalam pengembangan energi baru terbarukan ini yang diatur oleh UU No.30 Tahun 2007 tentang energi dalam $\mathrm{BAB}$ VI mengenai wewenang pemerintah dan pemerintah daerah dalam pasal 26 butir 2 menjelaskan bahwa pembuatan perda provinsi, pembinaan, pengawasan usaha di lintas kota/kabupaten serta penetapan kebijakan pengelolaan di lintas kota/kabupaten menjadi kewenangan pemerintah provinsi di bidang energi. Walaupun demikian dalam melaksanakan pengembangan energi baru terbarukan ini masih ada kendala yang dihadapi oleh Dinas ESDM Sumatera Barat yaitu ada juga masyarakat yang masih belum merasakan dampak dari pengembangan PLTMH dikarenakan ada beberapa PLTMH yang tidak berfungsi yang disebabkan oleh bencana alam seperti longsor dan banjir di daerah Sungai Kunyit yang merusak bendungan PLTMH, kurangnya teknisi yang dapat memperbaiki kerusakan pada PLTMH seperti generator dan turbin, kurangnya biaya yang dihasilkan dari pelnggan PLTMH dan sebagian dari jaringan listrik PLN sudah masuk ditambah lagi dengan investor yang tidak serius dalam pengembangan pembangkit listrik.

\section{TINJAUAN PUSTAKA}

\section{Konsep Implementasi}

Dari beberapa teori tentang proses kebijakan diperoleh tiga kata kunci yaitu formula, implementasi, dan kinerja. Sebuah kbijakan setelah diformulasikan, tahap selanjutnya adalah pengimplementasian kebijakan tersebut. Nugroho (2014) menjelaskan, 20\% keberhasilan kebijakan adalah rencana, $60 \%$ pada implementasi dan $20 \%$ adalah tentang bagaimana pengendalian implementasi atau penerapan. Bagian atau tahap paling berat adalah tahap implementasi kebijakan, terkadang pada tahap ini ditemukan masalah di lapangan yang sebelumnya tidak teridentifikasi di konsep. Selain daripada itu, konsistensi implementasi juga menjadi ancaman utama. Terdapat dua ciri dari sebuah kebijakan publik (Nugroho, 2014), yakni: 1) Kebijakan publik adalah suatu hal yang mudah dimengerti dan dipahami, sebab makna dari kebijakan adalah suatu hal yang akan dilaksanakan untuk menggapai tujuan nasional dan 2) kebijakan publik adalah suatu hal yang dapat diukur, sebab ukuran yang jelas (dapat dipahami) akan mampu mengukur progress kemajuan cita-cita ingin dicapai.

Implementasi merupakan salah satu bentuk upaya dari pemerintah sebagai penyelenggara kebijakan dalam menerapkan sebuah kebijakan atau kegiatan-kegiatan yang telah di sepepakati dalam bentuk kerjasama dengan berbagai lembaga terkait untuk mencapai keberhasilan suatu tujuan secara efektif dan efisien. Dengan artian karena keberhasilan suatu kebijakan tergantung bagaimana proses implementasi tersebut apakah sudah efektif atau belum efektif. Semakin tinggi tingkat kebijakan yang titerapkan maka akan semakin besar pula tingkat kesulitan dan keberhasilan dalam penerapan sebuah kebijakan. (Mubarak, 2012).

Oleh sebab itu, diperoleh kesimpulan bahwa implementasi atau penerapan kebijakan publik merupakan kegiatankegiatan yang dilaksanakan oleh pemerintah dalam bentuk kerjasama antar pelbagai lembaga sebagai upaya untuk memenuhi kebutuhan publik. Dalam pelaksanaan kebijakan tersebut dilakukan secara efektif dan efisien. 
Givan Dwiguna, Adil Mubarak I Implementasi Pengembangan Energi Baru Terbarukan Pembangkit Listrik Tenaga Mikro Hidro (PLTMH) oleh Dinas Energi dan Sumber Daya Mineral Provinsi Sumatera Barat di Solok Selatan

\section{Model-model Implementasi}

1) Model Pendekatan Implementasi Kebijakan oleh Van Meter \& Van Horn Van Meter \& Van Horn pada tahun 1975 memperkenalkan model pendekatan Implementasi Kebijakan dengan nama $A$ Model of the Policy Implementation. Model ini melakukan pengandaian bahwa implementasi kebijakan mulai dari kebijakan publik, implementor, dan kinerja kebijakan publik berjalan dengan beriringan (linear). Di dalam model ini disebutkan bahwa terdapat beberapa variabel yang mempengaruhi kinerja kebijakan dan saling berkaitan. Beberapa variabel tersebut ialah: 1) ukuran dan tujuan atau standar dan sasaran, 2) sumber daya, 3) ciri dan karakteristik penyelenggara, 4) sikap para pelaksana, 5) komunikasi dan kegiatan antar lembaga atau organisasi pelaksana yang terlibat, 6) kondisi sosial, politik, dan ekonomi.

2) Model implementasi Ewards III Model pendekatan implementasi kebijakan oleh Edwards III adalah Implementation Problem Approach (Mulyadi, 2016). Edwads menyebut keberhasilan dalam proses implementasi kebijakan dipengaruhi 4 faktor yang menjadi syarat utama. Ke-empat faktor tersebut ialah:

a) Komunikasi. Komunikasi sebuah program hanya bisa dilakukan dengan baik jika ada kejelasan bagi para pelaksana. Komunikasi yang dimaksud menyangkut kejelasan, proses penyampaian dan konsistensi informasi yang diteruskan.

b) Sumber Daya. Dalam implementasi kebijakan terdapat empat komponen yang menjadi sumber daya yakni staf yang cukup baik jumlah maupun mutu, data yang diperlukan untuk pengambilan keputusan, kewenangan yang cukup yang diperlukan untuk pelaksanaan tugas dan tanggung jawab juga sarana/prasarana yang diperlukan untuk pelaksanaan penerapan kebijakan.

c) Sikap Birokrasi atau Pelaksana. Komitmen pelaksana atas program yang dilaksanakan bergantung kepada sikap birokrasi atau sikap pelaksana.

d) Struktur organisasi. Tata laksana alur pekerjaan juga pelaksanaan program kebijakan diatur di dalam sebuah alur kerja birokrasi yang termuat dalam sebuah struktus organisasi.

\section{Energi Baru dan Terbarukan}

Pengertian energi baru di dalam Perpres No. 5 Tahun 2006 tentang Kebijakan Energi Nasional, pasal 1 butir 5 merupakan salah satu bentuk energi yang bersumber dari energi yang terbarukan dan tidak terbarukan yang diperoleh dengan teknologi baru yang dikembangkan. Contohnya nuklir, batubara yang dicairkan (liquefied coal), coal bed methane, batubara yang digaskan (gasified coal) dan hydrogen.

Dalam pasal 1 butir 6 juga menyatakan bahwa energi terbarukan dihasilkan oleh sumber daya energi bersifat alami yang berarti tidak cepat habis serta dapat bekelanjutan jikalau melalui pengelolaan yang baik. Energi terbarukan tersebut diantaranya panas bumi, panas surya, angin, aliran air sungai, bahan bakar nabati (biofuel), biogas, biomassa, suhu kedalaman laut, dan ombak laut.

\section{METODE PENELITIAN}

Studi penelitian ini menggunakan pendekatan kualitatif dengan metode deskriptif. Informan atau narasumber penelitian ditentukan secara purposive. Informan penelitian di sini yaitu Dinas ESDM Provinsi Sumatera Barat bagian Kabag Energi dan Ketenaga Listrikan, Dinas Penanaman Modal Pelayanan Terpadu Satu Pintu dan salah satu masyarakat umum. wawancara, observasi dan studi dokumentasi dilaksanakan untuk memperoleh dan mengumpulkan data. Sementara uji keabsahan data dilakukan 
Givan Dwiguna, Adil Mubarak I Implementasi Pengembangan Energi Baru Terbarukan Pembangkit Listrik Tenaga Mikro Hidro (PLTMH) oleh Dinas Energi dan Sumber Daya Mineral Provinsi Sumatera Barat di Solok Selatan

melalui reduksi data, display data, serta penulisan kesimpulan penelitian.

\section{HASIL DAN PEMBAHASAN}

Implementasi dalam Pengembangan Energi Baru Terbarukan PLTMH oleh Dinas ESDM Provinsi Sumatera Barat di Solok Selatan

Berdasarkan deskripsi diatas, diperoleh gambaran tentang Implementasi dalam pengembangan Energi Baru Terbarukan PLTMH oleh Dinas ESDM Provinsi Sumatera Barat di Solok Selatan, faktorfaktor yang mempengaruhi, kendala yang ditemui dan dihadapi serta upaya yang ditempuh untuk menangani kendala tersebut. Implementasi dalam pengembangan Energi baru terbarukan PLTMH oleh Dinas ESDM Provinsi Sumatera Barat di Solok Selatan tidaklah selalu berjalan dengan baik. Untuk itu peneliti menggunakan faktor-faktor penererapan E-Government yang diperkenalkan oleh Edwards III dalam meninjau Implementasi Pengembangan Energi Baru Terbarukan PLTMH oleh Dinas ESDM Provinsi Sumatera Barat di Solok Selatan.

\section{a) Komunikasi}

Pentingnya koordinasi dan komunikasi untuk sinkronisasi program dan kegiatan terkait energi baru dan terbarukan. Walaupun terkendala oleh keterbatasan anggaran, pemerintah daerah tetap berupaya memberikan bantuan sambungan listrik kepada keluarga miskin dalam bentuk paket bantuan bekerja sama dengan PT PLN hal tersebut di dukung juga oleh adanya komunikasi yang baik dari masyarakat dalam memberikan informasi bagi daerah mana yang membutuhkan, Dinas ESDM sangat menyadari bahwa jika Solok Selatan hanya mengandalkan listrik dari PT PLN, tidak akan dapat mencapai seluruh kepala keluarga dan jangka waktunya juga akan lama. Untuk itu, komunikasi dilakukan dengan pemerintah pusat, yang direpresentasikan oleh Kementerian ESDM lewat Direktorat
Jenderal Listrik dan Pemanfaatan Energi (DJLPE). Dinas ESDM menyebutkan bahwa bantuan pemerintah pusat sudah siap, berupa picohydro (Indonesia Environment Consultant 2012). Picohydro (pikohidro) merupakan pembangkit pemanfaatan energi air skala kecil di bawah $5 \mathrm{~kW}$ Hanya saja, kajian teknis di lapangan tentang implementasi pemanfaatan energi air skala kecil tetap perlu dilakukan. Tujuannya terutama untuk dapat menemukan lokasi yang sesuai dari sisi potensi dan kapasitas unit pembangkitnya, hal tersebut.

Jika dikaitkan dengan teori Edwar III dimana komunikasi sebuah program hanya akan berjalan baik apabila ada kejelasan informasi bagi para pelaksana. Komunikasi menyangkut kejelasan, proses penyampaian serta konsistensi informasi yang diteruskan.

b) Sumber Daya

Untuk mencapai target terlaksananya program PLMTH, pemerintah melaksanakan strategi penerapan konservasi (pemeliharaan dan perlindungan) energi. Strategi tersebut dilakukan dengan cara menumbuhkembangkan kesadaran masyarakat atas konservasi energi, mengoptimalkan kemampuan masyarakat serta penguasaan teknologi, melaksanakan monitoring dan evaluasi, juga melakukan pengawasan di bidang konservasi energi. Tanpa adanya sumber daya manusia yang bagus sebuah program belum tentu bisa terlaksana dengan baik, maka pemerintah berusaha melakukan peningkatan SDM dengan mengadakan pelatihan kepada masyarkat di bawah binaan dari Dinas ESDM Provinsi Sumatera Barat di Solok Selatan. Adanya dukungan investor juga diperlukan agar bisa memberi manfaat pada daerah khususnya masyarakat.

Jika dikaitkan dengan teori Edwar III sumber daya komponen yang cukup 
Givan Dwiguna, Adil Mubarak I Implementasi Pengembangan Energi Baru Terbarukan Pembangkit Listrik Tenaga Mikro Hidro (PLTMH) oleh Dinas Energi dan Sumber Daya Mineral Provinsi Sumatera Barat di Solok Selatan

(jumlah dan mutu). Dimana sumber daya yang dimanfatkan haruslah dilakukan semaksimal mungkin agar terlaksananya program PLMTH yang didukung bukan hanya oleh dinas energi tetapi juga oleh masyarakat dan investor. Sehingga kedepan ketersediaan sumber daya dapat dimanfaatkan secara optimal.

\section{c) Sikap Birokrasi atau Pelaksana}

Kebijakan Energi Nasional menjadi acuan dalam menentukan target konservasi energi. Target tersebut ialah menurunkan intensitas penggunaan energi $1 \%$ per-tahun sampai tahun 2025 dan menjangkau penghematan energi final hingga $17 \%$ pada tahun 2025. Mengimplementasikan mandat manajemen energi untuk konsumen energi $\geq 6.000$ TOE per-tahun, mengimplementasikan standar serta label efisiensi energi bagi peralatan dan mengimplementasikan konservasi energi di lingkungan $\mathrm{K} / \mathrm{L}$, seperti mendorong keterlibatan swasta untuk berinvestasi pada sektor konservasi energi.

Pengembangan energi baru terbarukan seperti PLTMH dan PLTS (Pembangkit Listrik Tenaga Surya) terus diupayakan oleh Pemerintah Provinsi Sumatera Barat melalui Dinas ESDM. Langkah ini ditempuh sebagai usaha memenuhi pasokan energi listrik di Sumatera Barat khususnya untuk masyarakat pedesaan yang belum terjangkau jaringan listrik PLN sebab letaknya yang berada di pelosok.

Jika di kaitkan dengan teori Edwar III sikap birorasi atau pelaksana ialah tentang komitmen pelaksana terhadap pelaksanaan program. Pengembangan energi baru terbarukan PLTMH dan PLTS terus dikerjakan oleh Dinas ESDM Provinsi Sumatera Barat. Langkah ini merupakan upaya dalam pemerataan pemenuhan kebutuhan energi listrik bagi warga masyarakat di Sumatera Barat khususnya daerah pedesaan yang belum terjangkau aliran listrik.

d) Struktur organisasi

Kebijakan dibuat, ditetapkan dan dilaksanakan ditujukan untuk penyelesaian masalah serta untuk mencapai tujuan tertentu. Pada tahun 2004 dengan Program Nasional Pemberdayaan Masyarakat (PNPM), pemerintah daerah kabupaten kembali membangun PLTMH berkordinasi dengan pemerintah pusat dimana strukuturnya dilihat dari top leader sampai pemerintahan di bawah. Pelaksanaan sebuah program tidak lepas dari bantuan pemerintah provinsi. Dengan memperhatikan sumber daya yang tersedia, pengembangan dan pembangunan fasilitas PLTMH terus diupayakan oleh pemerintah daerah.

Jika di kaitkan dengan teori Edwar III sebuah program termasuk tata laksana alur kerja birokrasi yang mengatur alur pekerjaan dan pelaksanaan kebijakan dimana dengan pemerintah pusat dimana strukuturnya dilihat dari top leader sampai pemerintahan di bawah dengan bawah pelaksananya sebuah program tidak lepas dari merupakan bantuan dari pemerintah provinsi.

\section{Kendala yang dihadapi oleh Dinas ESDM Provinsi Sumatera Barat dalam mengembangkan energi baru terbarukan di Solok Selatan}

a) Internal

Dalam pengembangan energi baru terbarukan (EBT), saat ini pemerintah telah melakukan penandatanganan komitmen terkait pengembangan energi baru terbarukan. Dalam upaya pemenuhan kebutuhan listrik nasional pemerintah juga melibatkan swasta dalam pengembangan EBT sebesar 66,6\% atau 8.808 MW dari total kapasitas yang akan dikembangkan yakni sebesar 13.232 MW. Ada beberapa 
Givan Dwiguna, Adil Mubarak I Implementasi Pengembangan Energi Baru Terbarukan Pembangkit Listrik Tenaga Mikro Hidro (PLTMH) oleh Dinas Energi dan Sumber Daya Mineral Provinsi Sumatera Barat di Solok Selatan

kendala yang dihadapi dalam upaya pengembangan EBT ini mulai dari segi pendanaan hingga hingga ketersediaan energi yang akan dimanfaatkan. Sebagai contoh, penggunaan panas bumi sebagai EBT memerlukan pengeboran pada daerah yag memiliki potensi cukup besar, proses pelaksanaannya membutuhkan waktu yang lama dan memerlukan sokongan dana yang besar ditambah dengan resiko kegagalan yang perlu diperkirakan agar dapat dikendalikan.

Anggaran dana dari pemerintah melalui Kementerian ESDM guna program listrik pedesaan masih terbatas. Anggaran listrik desa untuk tahun 2019 hanya disetujui sebesar 5,9 triliun, dari usulan 8,5 triliun. Pengurangan anggaran ini menghambat elektrifikasi untuk daerah 3T dan berdampak pada lebih lamanya proses untuk penyaluran aliran listrik terhadap desa-desa yang belum mendapatkan akses listrik. Program ini seyogyanya diimbangi dengan perencanaan jangka panjang sehingga energi yang dinikmati masyarakat merupakan energi yang benar-benar dapat digunakan untuk kegiatan yang produktif.

\section{b) Eksternal}

Salah satu kendala yang menjadi penghambat dalam pengembangan pembangkit tenaga air skala kecil adalah masih rendahnya sumber daya mineral. Untuk sebuah pembangkit listrik memerlukan sebuah komponen penggerak mula (turbin), untuk pengadaannya perlu melakukan pemesanan terlebih dahulu. Proses pengadaan ini memerlukan biaya yang tidak sedikit, harga per unit turbin bisa menjadi mahal karena membutuhkan biaya survei dan perencanaan. Sementara biaya survei dan perencanaan ini dibebankan kepada masyarakat.

Kabupaten Solok Selatan, Sumatera barat menjadi salah satu sumber energi potensial. Lebih dari 160 Megawatt listrik dihasilkan dari pemanfaatan arus sungai, salah satunya Sungai Batang Sangir. Hal ini telah dimanfaatkan oleh beberapa BUMN maupun Perusahaan Swasta sebagai alternatif sumber potensial energi listrik terbarukan. Hal ini sepatutnya menjadi perhatian, kedepan diharapakan hadirnya investor luar yang mau mengembangkan dan berinvestasi di sektor energi terbarukan di Solok, agar program pengembangan EBT dapat terlaksana dengan baik.

\section{PENUTUP}

Optimalisasi pemanfaatan energi baru terbarukan ditujukan untuk menekan ketergantungan manusia terhadap energi fosil seperti batubara, gas dan minyak bumi. Sejalan dengan hal itu, pemanfaatan energi baru terbarukan dilakukan sebagai usaha untuk mendukung program go green, mengurangi polusi udara serta menciptakan lingkungan yang bersih dan lebih aman di lingkungan pembangkit listrik. Hal ini juga diharapkan mampu menjawab kebutuhan dunia akan kebutuhan energi yang ramah terhadap lingkungan. Saat ini, mulai tumbuh kesaradarn konsumen akan energi yang ramah lingkungan, hal ini ditandai dengan adanya kehendak konsumen listrik untuk menggunakan energi yang dihasilkan dari energi yang ramah lingkungan (Renewable Energy) dalam proses produksinya walaupun dengan tarif yang lebih tinggi dari biasanya.

Alokasi anggaran pemerintah melalui Kementerian ESDM untuk program listrik pedesaan sendiri masih terbatas. Anggaran listrik desa untuk tahun 2019 hanya disetujui sebesar 5,9 triliun, dari usulan 8,5 triliun. Pengurangan anggaran ini menghambat elektrifikasi untuk daerah $3 \mathrm{~T}$ dan berdampak pada lebih lamanya proses untuk penyaliran listrik di desa-desa yang belum mendapatkan akses listrik. Program ini seyogyanya diimbangi dengan perencanaan jangka panjang sehingga energi yang dinikmati masyarakat merupakan energi yang benar-benar dapat digunakan untuk kegiatan yang produktif. 


\section{DAFTAR KEPUSTAKAAN}

BPHN. (1985). Presiden republik indonesia. Peraturan Pemerintah Republik Indonesia Nomor 26 Tahun 1985 Tentang Jalan, 1, 1-5. https://doi.org/10.1016/j.aquaculture.2 007.03.021

KESDM. (2007). UU 30/2007_Energi. 121.

Mubarak, A. (2012). Model Impelementasi Program dalam Upaya Pencapaian Sasaran MDGs 2015 (Strategi Bagi Birokrasi Sebagai Ujung Tombak Implementasi 8 sasaran MDGs). Universitas Terbuka, 1-14. 8(1), 1-4.

Nugroho, R. (2017). Public Policy: Dinamika Kebijakan, Analisis Kebijakan, dan Manajemen Politik Kebijakan Publik. In Jakarta: Elex Media Komputindo. https://doi.org/10.1017/S00332917020 06190

Prof, Dr, Mulyadi, Deddy, Drs., M. s. (2016). Studi Kebijakan Publik dan Pelayanan Publik. In Carbohydrate Polymers. https://doi.org/10.1109/MTAS.2004.1 371634 